\title{
DEVELOPMENT AND VALIDATION OF A STABILITY INDICATING REVERSE PHASE- HIGH PERFORMANCE LIQUID CHROMATOGRAPHY METHOD FOR SIMULTANEOUS DETERMINATION OF CLINDAMYCIN, METRONIDAZOLE, AND CLOTRIMAZOLE IN PHARMACEUTICAL COMBINED DOSAGE FORMS
}

\author{
REVATHI NAGA LAKSHMI PONNURI ${ }^{1 *}$, PRAHLAD PRAGALLAPATI ${ }^{2}$, MASTANAMMA SK $^{3}$, RAVINDRA N $^{4}$, \\ VENKATA BASAVESWARA RAO MANDAVA ${ }^{5}$, BORUSU SRI NAGA SUDHA ${ }^{6}$, KOPPISETTI BALADURGA PRASAD ${ }^{7}$
}

${ }^{1}$ Department of Pharmacy, Faculty Pharmaceutical Sciences, Pharmaceutical Analysis, Krishna University, Machilipatnam - 521002, Andhra Pradesh, India. ${ }^{2}$ Department of Pharmaceutics, Acharya Nagarjuna University, Guntur - 522 510, Andhra Pradesh, India.

${ }^{3}$ Department of Pharmaceutical Analysis, Acharya Nagarjuna University, Guntur - 522 510, Andhra Pradesh, India. ${ }^{4}$ Department of Pharmaceutical Chemistry, Chilkur Balaji College of Pharmacy, Hyderabad - 500 075, Telangana, India. ${ }^{5}$ Faculty of Sciences, Directorate of Admissions, Department of Chemistry, Krishna University, Machilipatnam- 521 002, Andhra Pradesh, India. ${ }^{6}$ Department of Pharmaceutical Analysis \& QA, Vj's College of Pharmacy, Rajahmundry, Andhra Pradesh, India. ${ }^{7}$ Hospira, A Pfizer Company, Vizag, Andhra Pradesh, India. Email: pharma_revathi@yahoo.com

Received: 23 July 2016, Revised and Accepted: 30 September 2016

\section{ABSTRACT}

Objective: The objective of present work was to develop and validate a simple, fast, precise, selective, and accurate reverse phase high-performance liquid chromatography method for the simultaneous determination of Clindamycine, Metronidazole and Clotrimazole in a pharmaceutical dosage form.

Methods: The separation of these three drugs was achieved on ODS $250 \times 4.6 \mathrm{~mm}, 5 \mu \mathrm{m} \mathrm{C}{ }_{18}$ column. Mobile phase containing $0.1 \%$ ortho phosphoric acid buffer and acetonitrile in the ratio of $55: 45 \mathrm{v} / \mathrm{v}$ was pumped through column at a flow rate of $1 \mathrm{ml} /$ minute. Temperature was maintained at $30^{\circ} \mathrm{C}$ and ultraviolet detection at $238 \mathrm{~nm}$.

Results: The retention times were observed to be 2.591, 3.584, and 4.221 minutes for Clindamycine, Metronidazole, and Clotrimazole, respectively. Linearity was found to be $25-150 \mu \mathrm{g} / \mathrm{ml}$ Clindamycine, Metronidazole, and Clotrimazole, respectively. The method was statistically validated for linearity, recovery, the limit of detection (LOD), limit of quantification (LOQ), accuracy, and precision. The stress testing of the drugs individually and their mixture are carried out under acidic, alkaline, oxidation, photostability, and thermal degradation conditions and its degradation products are well resolved from the analyte peaks.

Conclusion: This method was successfully validated for accuracy, precision, and linearity, LOD, and LOQ.

Keywords: Clindamycine, Metronidazole, Clotrimazole, Reverse phase-high performance liquid chromatography, Simultaneous determination, Degradation studies.

(C) 2017 The Authors. Published by Innovare Academic Sciences Pvt Ltd. This is an open access article under the CC BY license (http://creativecommons, org/licenses/by/4. 0/) DOI: http://dx.doi.org/10.22159/ajpcr.2017.v10i1.14273

\section{INTRODUCTION}

Clindamycine [1-3] is a semisynthetic lincosamide antibiotic that has largely replaced lincomycin due to an improved side effect profile. Clindamycine inhibits bacterial protein synthesis by binding to bacterial $50 \mathrm{~S}$ ribosomal subunits. It may be bacteriostatic or bactericidal depending on the organism and drug concentration. The International Union of Pure and Applied Chemistry (IUPAC) name is $(2 \mathrm{~S}, 4 \mathrm{R})-\mathrm{N}-\{2$-chloro-1-[(2R,3R,4S,5R,6R)-3,4,5-trihydroxy6-(methylsulfanyl)oxan-2-yl]propyl\}-1-methyl-4 propylpyrrolidine2-carboxamide. Structure was shown in Fig. 1. Metronidazole [4-7] is a prodrug. Unionized Metronidazole is selective for anaerobic bacteria due to their ability to intracellularly reduce Metronidazole to its active form. This reduced Metronidazole then covalently binds to deoxyribonucleic acid, disrupt its helical structure, inhibiting bacterial nucleic acid synthesis, and resulting in bacterial cell death. IUPAC name is 2-(2-methyl-5-nitro-1H-imidazol-1-yl) ethan-1-ol. The structure was shown in Fig. 1. Clotrimazole [8-10] is an imidazole derivative and an antifungal compound and a CYP (cytochrome P450) inhibitor. Clotrimazole has been shown to block

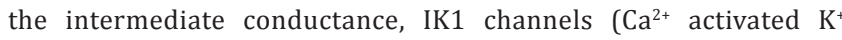
channels), in cells such as erythrocytes. In vitro studies of various yeast strains have demonstrated susceptibility to Clotrimazole. Clotrimazole is an activator of MB67 and an inhibitor of CYP3A4 and
CYP51A1. IUPAC name is 1-[(2-chlorophenyl)diphenylmethyl]-1Himidazole. The structure was shown in Fig. 1.

The literature survey reveals that so far there are only two analytical methods are reported for simultaneous estimation of Clindamycine, Metronidazole, and Clotrimazole $[11,12]$. The first method reported by Seethalakshmi et al. [11] utilizes a mobile phase flow rate of $2.3 \mathrm{ml} /$ minute with 40 minutes runtime.

The second method reported by Raendar et al. is the only one stability indicating method published for the simultaneous estimation of Clindamycine, Metronidazole, and Clotrimazole [12] having phosphate buffer $\mathrm{pH}$ 4.5:methanol:acetonitrile in the ratio of $30: 20: 50 \% \mathrm{~V} / \mathrm{V}$ as mobile phase, $\mathrm{pH} 4.5$ adjusted by using $0.1 \mathrm{M}$ ortho phosphoric acid (OPA) with runtime of 10 minutes. The LOD and LOQ of Metronidazole, Clindamycin, and Clotrimazole were found to be 1.77 and $5.35 \mu \mathrm{g} / \mathrm{ml}$, 2.55 and $7.77 \mu \mathrm{g} / \mathrm{ml}$, and 1.28 and $5.25 \mu \mathrm{g} / \mathrm{ml}$, respectively.

Hence, we have planned to develop a simple, precise, economic, and accurate stability indicating reverse phase-high performance liquid chromatography (RP-HPLC) method for the estimation of Clindamycine, Metronidazole, and Clotrimazole in bulk and pharmaceutical dosage form according to the International Conference on Harmonization (ICH) [13-18] Guidelines. 


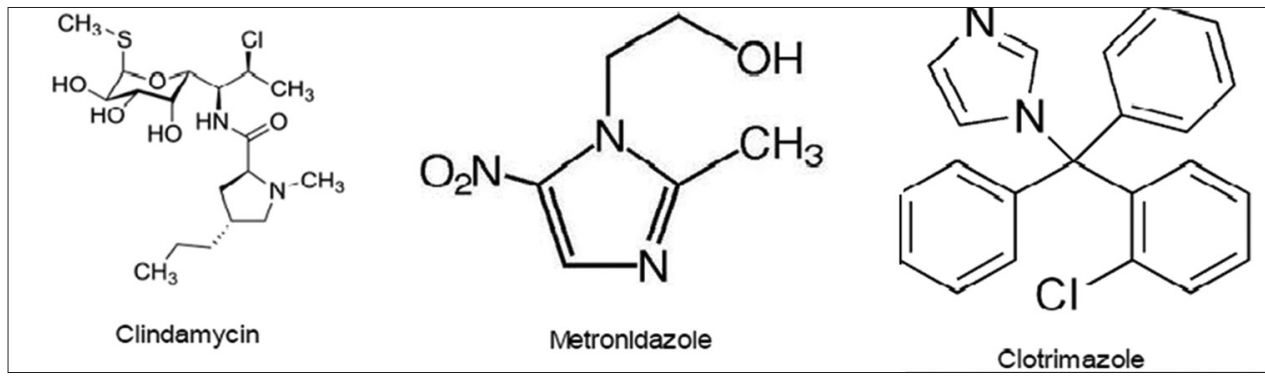

Fig. 1: Structures of Clindamycine, Metronidazole, and Clotrimazole

Finally, developed and validated the method with the comparative betterment of following parameters. Mobile phase containing 0.1\% OPA buffer and acetonitrile in the ratio of $55: 45 \mathrm{v} / \mathrm{v}$ was pumped through column at a flow rate of $1 \mathrm{ml} /$ minute ( 8 minutes runtime). The LOD and LOQ of Metronidazole, Clindamycine, and Clotrimazole were found to be 0.095 and $0.290 \mu \mathrm{g} / \mathrm{ml}, 0.19$ and $0.589 \mu \mathrm{g} / \mathrm{ml}$, and 0.135 and 0.12 $\mu \mathrm{g} / \mathrm{ml}$, respectively. [19-22].

Importance of analytical method, presented in this publication, is an application to the assay of Vagi CL formulation. Vagi CL having lot of advantages for treating of amoebiasis, anaerobic infections, and antibiotic-associated colitis. Till date, no official methods developed for combination of Vagi CL. Hence, this method can be used for routine analysis of Vagi CL in industries.

\section{METHODS}

Active pharmaceutical ingredients Clindamycine, Metronidazole, and Clotrimazole were obtained as a gift sample from Spectrum Pharma Research Solutions, Hyderabad. The pharmaceutical dosage form (Vagi CL [Vaginal Pessary] from Rekvina Pharmaceuticals India Pvt., Ltd) was purchased from local pharmacy. The solvents used in this work were of HPLC grade and obtained from the Merck Specialties Private Limited, Mumbai.

\section{Instrumentation and chromatographic conditions}

The analysis was performed on a HPLC system consists of waters 2695 with 2996 module Photo Diode Array detector equipped with a quaternary solvent delivery pump, automatic sample injector, and column thermostat. The data acquisition and analysis was performed using Empower2 software. The chromatographic separation was performed on ODS $\mathrm{C}_{18}$ column $(250 \times 4.6 \mathrm{~mm} \times 5 \mu)$. The flow rate was kept at $1 \mathrm{ml} /$ minute. The column temperature was maintained at $30^{\circ} \mathrm{C}$. The mobile phase was made of $0.1 \%$ OPA buffer and acetonitrile in 55:45 ratio had gave acceptable retention time and good resolution between Clindamycine, Metronidazole, and Clotrimazole. The method was optimized at $238 \mathrm{~nm}$. Data acquisition and processing was performed using Empower2 system software. The run time was taken as 8 minutes. All the determinations are carried out at an ambient temperature.

\section{Sample processing}

\section{Preparation of standard stock solutions}

Accurately weighed $10 \mathrm{mg}$ of Clindamycine, $10 \mathrm{mg}$ of Metronidazole, and $10 \mathrm{mg}$ of Clotrimazole and transferred to three $10 \mathrm{ml}$ volumetric flasks separately. $7 \mathrm{ml}$ of diluent was added to flasks and sonicated for 15 minutes. Flasks were made up with diluent and labeled as standard stock solution 1, 2, and $3.1 \mathrm{ml}$ from each stock solution was pipette out and taken into a $10 \mathrm{ml}$ volumetric flask and made up with diluent.

\section{Preparation of sample stock solutions}

5 pessaries were weighed and calculated the average weight of each pessary, then the weight equivalent to one pessary and transferred into a $100 \mathrm{ml}$ volumetric flask, $70 \mathrm{ml}$ of diluent added and sonicated for 25 minutes, further the volume made up with diluent and filtered. From the filtered solution, $1 \mathrm{ml}$ was pipette out into a $10 \mathrm{ml}$ volumetric flask and made up to $10 \mathrm{ml}$ with diluent.

\section{Preparation of buffer}

Buffer: (0.1\% OPA)

About $1 \mathrm{ml}$ of OPA in a $1000 \mathrm{ml}$ of volumetric flask adds about $100 \mathrm{ml}$ of milli-Q water and final volume make up to $1000 \mathrm{ml}$ with milli-Q water.

\section{Method validation}

The method was validated according to the ICH guidelines. The different validation characteristics which were performed are following: Linearity, accuracy, precision, limit of detection (LOD), limit of quantification (LOQ), robustness, and the stability indicating capability.

System suitability parameters

The system suitability parameters were determined by preparing standard solutions of Clindamycine, Metronidazole, and Clotrimazole, and the solutions were injected 6 times and the parameters such as peak tailing, resolution, and the United States Pharmacopeia (USP) plate count were determined.

Linearity

The linearity of the method is determined by preparing three individual series of solutions in the range of Clindamycine $(25-150 \mu \mathrm{g} / \mathrm{ml}$ ), Metronidazole (25-150 $\mu \mathrm{g} / \mathrm{ml})$, and Clotrimazole (25-150 $\mu \mathrm{g} / \mathrm{ml})$. The obtained peak areas are plotted against concentration.

\section{Preparation of linearity solutions}

\section{Preparation of standard stock solutions}

Accurately weighed $10 \mathrm{mg}$ of Clindamycine, $10 \mathrm{mg}$ of Metronidazole, and $10 \mathrm{mg}$ of Clotrimazole and transferred to three $10 \mathrm{ml}$ volumetric flasks separately. $7 \mathrm{ml}$ of diluent was added to flasks and sonicated for 15 minutes. Flasks were made up with diluent and labeled as standard stock solution 1, 2, and 3. From three stock solutions pipette out 0.25 , $0.5,0.75,1.0,1.25$, and $1.50 \mathrm{ml}$ into $10 \mathrm{ml}$ volumetric flask to get $25 \%$, $50 \%, 75 \%, 100 \%, 125 \%$, and $150 \%$, respectively, of standard solutions.

\section{Precision}

Method precision (repeatability)

The method precision/repeatability can be determined by injecting six working standard solutions and six sample injections. The areas of all the injections were taken and standard deviation (SD), \%relative standard deviation (\%RSD), and \%assay were calculated.

\section{Intermediate precision}

The intermediate precision can be determined by injecting six working standard solutions and six sample injections on different days by different operators or by different instruments. The areas of all the injections were taken and SD, \%RSD, and \%assay were calculated. The results obtained were within the acceptance criteria.

\section{Accuracy}

Accuracy is tested by the standard addition method at three different levels $50 \%, 100 \%$, and $150 \%$. The percentage recoveries 
of Clindamycine, Metronidazole, and Clotrimazole present in the pharmaceutical dosage form were calculated.

\section{Preparation of $50 \%$ spiked solution}

5 pessaries were weighed and calculated the average weight of each pessary, then the weight equivalent to one pessary and transferred into a $100 \mathrm{ml}$ volumetric flask, $70 \mathrm{ml}$ of diluent added, and sonicated for 25 minutes, further the volume made up with diluent and filtered. $1 \mathrm{ml}$ from each standard stock solution was pipette out and taken into a $10 \mathrm{ml}$ volumetric flask to that $0.5 \mathrm{ml}$ of filtered accuracy standard stock solution was spiked and made up with diluents.

\section{Preparation of $100 \%$ spiked solution}

5 pessaries were weighed and calculated the average weight of each pessary, then the weight equivalent to one pessary and transferred into a $100 \mathrm{ml}$ volumetric flask, $70 \mathrm{ml}$ of diluent added, and sonicated for 25 minutes, further the volume made up with diluent and filtered. $1 \mathrm{ml}$ from each standard stock solution was pipette out and taken into a $10 \mathrm{ml}$ volumetric flask to that $1 \mathrm{ml}$ of filtered accuracy standard stock solution was spiked and made up with diluents.

\section{Preparation of $\mathbf{1 5 0} \%$ spiked solution}

5 pessaries were weighed and calculated the average weight of each pessary, then the weight equivalent to one pessary and transferred into a $100 \mathrm{ml}$ volumetric flask, $70 \mathrm{ml}$ of diluent added, and sonicated for 25 minutes, further the volume made up with diluent and filtered. $1 \mathrm{ml}$ from each standard stock solution was pipette out and taken into a $10 \mathrm{ml}$ volumetric flask to that $1.5 \mathrm{ml}$ of filtered accuracy standard stock solution was spiked and made up with diluents.

\section{LOD and LOQ}

LOD and LOQ of Clindamycine, Metronidazole, and Clotrimazole were determined by calibration curve method. Solutions of Clindamycine, Metronidazole, and Clotrimazole were prepared in linearity range and injected in triplicate. Average peak area of three analyses was plotted against concentration.

\section{Method robustness}

The robustness can be determined by varying the following parameters:

Robustness of the developed method was determined by making small deliberate changes in flow rate $( \pm 0.1 \mathrm{ml} /$ minute $)$, column temperature $( \pm 5 \%)$, organic mobile phase ratio $( \pm 10 \%)$, along with the optimized method.

\section{Forced degradation studies \\ Oxidation}

To $1 \mathrm{ml}$ of stock solution of Clindamycine, Metronidazole, and Clotrimazole, $1 \mathrm{ml}$ of $20 \%$ hydrogen peroxide $\left(\mathrm{H}_{2} \mathrm{O}_{2}\right)$ was added separately. The solutions were kept for 30 minutes at $60^{\circ} \mathrm{C}$. For HPLC study, the resultant solution was diluted to obtain 100,100, and $100 \mu \mathrm{g} / \mathrm{ml}$ of all components, and $10 \mu \mathrm{l}$ was injected into the system and the chromatograms were recorded to assess the stability of sample.

\section{Acid degradation studies}

To $1 \mathrm{ml}$ of stocks solution Clindamycine, Metronidazole, and Clotrimazole, $1 \mathrm{ml}$ of $2 \mathrm{~N}$ hydrochloric acid was added and refluxed for 30 minutes at $60^{\circ} \mathrm{C}$. The resultant solution was diluted to obtain 100,100 , and $100 \mu \mathrm{g} / \mathrm{ml}$ of all components, and $10 \mu \mathrm{l}$ solutions was injected into the system and the chromatograms were recorded to assess the stability of sample.

\section{Alkali degradation studies}

To $1 \mathrm{ml}$ of stock solution Clindamycine, Metronidazole, and Clotrimazole, $1 \mathrm{ml}$ of $2 \mathrm{~N}$ sodium hydroxide was added and refluxed for 30 minutes at $60^{\circ} \mathrm{C}$. The resultant solution was diluted to obtain 100 , 100 , and $100 \mu \mathrm{g} / \mathrm{ml}$ of all components, and $10 \mu \mathrm{l}$ was injected into the system and the chromatograms were recorded to assess the stability of sample.

\section{Dry heat degradation studies}

The standard drug solution was placed in oven at $105^{\circ} \mathrm{C}$ for $6 \mathrm{hrs}$ to study dry heat degradation. For HPLC study, the resultant solution was diluted obtain 100,100 , and $100 \mu \mathrm{g} / \mathrm{ml}$ of all components, and $10 \mu \mathrm{l}$ was inject $d$ into the system and the chromatograms were recorded to assess the stability of the sample.

\section{Photostability studies}

The photochemical stability of the drug was also studied by exposing 1000,1000 , and $1000 \mu \mathrm{g} / \mathrm{ml}$ solution to ultraviolet (UV) light by keeping the beaker in UV chamber for 7 days or $200 \mathrm{~W} \mathrm{~h} / \mathrm{m}^{2}$ in photostability chamber. For HPLC study, the resultant solution was diluted to obtain 100,100 , and $100 \mu \mathrm{g} / \mathrm{ml}$ of all components, and $10 \mu \mathrm{l}$ was injected into the system and the chromatograms were recorded to assess the stability of sample.

\section{Neutral degradation studies}

Stress testing under neutral conditions was studied by refluxing the drug in water for $6 \mathrm{hrs}$ at a temperature of $60^{\circ}$. For HPLC study, the resultant solution was diluted to obtain 100,100, and $100 \mu \mathrm{g} / \mathrm{ml}$ of all components, and $10 \mu \mathrm{l}$ was injected into the system and the chromatograms were recorded to assess the stability of the sample.

\section{RESULTS AND DISCUSSIONS}

\section{Development and optimization of HPLC method}

The present work was focused to develop a stability indicating RP-HPLC method for the simultaneous estimation of Clindamycine, Metronidazole, and Clotrimazole in pharmaceutical dosage form. The solubility of the active pharmaceutical ingredient was checked in different solvents such as methanol, water, acetonitrile, and in different ratios, but finally, the standard is soluble in water:acetonitrile (50:50), so it was chosen as a diluent. The different mobile phases such as acetonitrile and water, acetonitrile and $0.01 \mathrm{~N}$ potassium dihydrogen ortho phosphate buffer, and acetonitrile and sodium dihydrogen phosphate buffer were used in compositions with a flow rate of $1 \mathrm{ml} /$ minute, but the peak resolution, retention time, and tailing factor were not satisfactory, so at last OPA and acetonitrile was selected as a buffer at flow rate of $1 \mathrm{ml} /$ minutes. Initially, "kromosil ${ }^{\circledR ”}(250 \times 4.6 \mathrm{~mm} \times 5 \mu)$ and "BDS ${ }^{\circledR} "$ $(150 \times 4.6 \mathrm{~mm} \times 5 \mu)$ columns with different temperatures such as $30^{\circ} \mathrm{C}$, $35^{\circ} \mathrm{C}, 40^{\circ} \mathrm{C}$, and $45^{\circ} \mathrm{C}$ were used, but the retention time, run time, and peak resolution were not exact and the problem was get rid using ODS $\mathrm{C}_{18}$ column $(250 \times 4.6 \mathrm{~mm} \times 5 \mu)$ kept at $30^{\circ} \mathrm{C}$ with a run time of 8 minutes. Finally, the method was optimized by altering the mobile phase composition/ratio and the optimized wavelength of three drugs Clindamycine, Metronidazole, and Clotrimazole was found to be at $238 \mathrm{~nm}$.

\section{System suitability parameters}

The system suitability tests were conducted before performing the validation, and the parameters were within the acceptance criteria such as retention times were 2.591, 3.584, and 4.221 minutes for Clindamycine, Metronidazole, and Clotrimazole; plate count was $>2000$; peak tailing was $<2$; the $\%$ RSD of peak areas of six injections were $\leq 2 \%$ (Table 1 ). Hence, the proposed method was successfully applied to routine analysis without any problems.

\section{Linearity range}

The linearity range was in the interval of Clindamycine (25-150 $\mu \mathrm{g} / \mathrm{ml})$, Metronidazole $(25-150 \mu \mathrm{g} / \mathrm{ml})$, and Clotrimazole (25-150 $\mu \mathrm{g} / \mathrm{ml})$, respectively. These were represented by a linear regression equation as follows: $Y$ (Clindamycine) $=13873 \mathrm{x}+1140$. $\left(r^{2}=0.999\right), \quad y \quad$ (Metronidazole $)=16591 x+886.2 \quad\left(r^{2}=0.999\right)$, and $y$ $($ Clotrimazole $)=13335 x+786.5$. Regression line was established by least squares method and correlation coefficient $\left(r^{2}\right)$ for Clindamycine, 
Metronidazole, and Clotrimazole were found to be greater than 0.999 . Hence, the curves established were linear (Table 2). Chromatograms were shown in Fig. 2.

\section{Precision}

Six replicates injections at the same concentration were analyzed on the same day and two different days for verifying the variation in the precision and the \%RSD for Clindamycine, Metronidazole, and Clotrimazole were within acceptable limit of $\leq 2$. Hence, the method is reproducible on different days with different analyst and column. This indicates that the method is precise (Table 3).

\section{Accuracy}

The percentage recoveries for Clindamycine, Metronidazole, and Clotrimazole were found to be $100.98 \%, 100.72 \%$, and $100.69 \%$, respectively (Tables 4-6). The results of the recovery studies undoubtedly demonstrate the accuracy of the proposed method.

\section{LOD and LOQ}

The determined values of LOD and LOQ were calculated using slope and Y-intercept. The LOD and LOQ values for Clindamycine were found to be 0.19 and $0.58 \mu \mathrm{g} / \mathrm{ml}$; Metronidazole were found to be 0.09 and $0.29 \mu \mathrm{g} / \mathrm{ml}$; Clotrimazole were found to be 0.13 and $0.41 \mu \mathrm{g} / \mathrm{ml}$, respectively (Table 7).

\section{Robustness}

Robustness of the proposed method demonstrated a nonsignifican alteration through analysis of the sample and standard Clindamycine, Metronidazole, and Clotrimazole solution (Table 8). After this, the results obtained were compared with that of optimized method. It was confirmed that by the deliberate changes in the parameters there was no any significant changes in SD, RSD, theoretical plates, retention time, and USP tailing factor.

\section{Assay}

The content of Clindamycine, Metronidazole, and Clotrimazole in the pharmaceutical dosage form were found using the developed method. The percentage purity of Clindamycine, Metronidazole, and Clotrimazole was found to be $100.78 \%, 100.84 \%$, and $100.54 \%$ and $\%$ RSD values for Clindamycine, Metronidazole, and Clotrimazole in were within the limit of $\leq 2$.

\section{Forced degradation studies}

The forced degradation studies were conducted and all the parameters for Clindamycine, Metronidazole, and Clotrimazole were within the limits. Clindamycine, Metronidazole, and Clotrimazole have shown significant sensitivity toward the treatment of $\mathrm{HCl}, \mathrm{NaOH}$, and peroxide solutions. The drugs gradually undergone degradation with time and prominent degradation was observed. Clindamycine, Metronidazole,

Table 1: System suitability parameters for Clindamycine, Metronidazole, and Clotrimazole

\begin{tabular}{|c|c|c|c|c|c|c|c|c|c|}
\hline \multirow{2}{*}{$\begin{array}{l}\text { S. No } \\
\text { Injection }\end{array}$} & \multicolumn{3}{|l|}{ Clindamycine } & \multicolumn{3}{|l|}{ Metronidazole } & \multicolumn{3}{|l|}{ Clotrimazole } \\
\hline & $\begin{array}{l}\text { Retention } \\
\text { time (minute) }\end{array}$ & $\begin{array}{l}\text { Number of } \\
\text { theoretical } \\
\text { plates }\end{array}$ & $\begin{array}{l}\text { Tailing } \\
\text { factor }\end{array}$ & $\begin{array}{l}\text { Retention } \\
\text { time (minute) }\end{array}$ & $\begin{array}{l}\text { Number of } \\
\text { theoretical } \\
\text { plates }\end{array}$ & $\begin{array}{l}\text { Tailing } \\
\text { factor }\end{array}$ & $\begin{array}{l}\text { Retention } \\
\text { time (minute) }\end{array}$ & $\begin{array}{l}\text { Number of } \\
\text { theoretical } \\
\text { plates }\end{array}$ & $\begin{array}{l}\text { Tailing } \\
\text { factor }\end{array}$ \\
\hline 1 & 2.575 & 6367 & 1.49 & 3.566 & 9984 & 1.19 & 4.194 & 10826 & 1.11 \\
\hline 2 & 2.582 & 6326 & 1.39 & 3.586 & 10152 & 1.19 & 4.216 & 11163 & 1.12 \\
\hline 3 & 2.591 & 6514 & 1.48 & 3.591 & 11029 & 1.22 & 4.225 & 10818 & 1.12 \\
\hline 5 & 2.598 & 6333 & 1.4 & 3.601 & 10055 & 1.2 & 4.238 & 10895 & 1.13 \\
\hline 6 & 2.601 & 6429 & 1.36 & 3.749 & 9646 & 1.18 & 4.466 & 10476 & 1.1 \\
\hline $\begin{array}{l}\text { Mean \% } \\
\text { recovery }\end{array}$ & 2.591 & 6428 & 1.41 & 3.615 & 10175 & 1.19 & 4.263 & 10825 & 1.12 \\
\hline $\begin{array}{l}\text { Standard } \\
\text { deviation }\end{array}$ & 0.0102 & 109.9776 & 0.0579 & 0.0667 & 460.5753 & 0.0151 & 0.1010 & 220.8669 & 0.0105 \\
\hline $\begin{array}{l}\text { Relative } \\
\text { standard } \\
\text { deviation } \\
\text { in } \%\end{array}$ & 0.39 & 1.71 & 4.09 & 1.84 & 4.53 & 1.26 & 2.37 & 2.04 & 0.94 \\
\hline
\end{tabular}

Table 2: Linearity table for Clindamycine, Metronidazole, and Clotrimazole

\begin{tabular}{|c|c|c|c|c|c|}
\hline \multicolumn{2}{|l|}{ Clindamycine } & \multicolumn{2}{|l|}{ Metronidazole } & \multicolumn{2}{|l|}{ Clotrimazole } \\
\hline Concentration $(\mu \mathrm{g} / \mathrm{ml})$ & Peak area & Concentration $(\mu \mathrm{g} / \mathrm{ml})$ & Peak area & Concentration $(\mu \mathrm{g} / \mathrm{ml})$ & Peak area \\
\hline 25 & 341795 & 25 & 404896 & 25 & 303196 \\
\hline 75 & 1043871 & 75 & 1253991 & 75 & 1025053 \\
\hline 100 & 1386674 & 100 & 1672361 & 100 & 1326643 \\
\hline 125 & 1725579 & 125 & 2072055 & 125 & 1656382 \\
\hline 150 & 2087619 & 150 & 2480096 & 150 & 1999226 \\
\hline
\end{tabular}

Table 3: Determination of repeatability and intermediate precision

\begin{tabular}{|c|c|c|c|c|c|c|}
\hline \multirow[t]{2}{*}{ Drug name } & \multicolumn{3}{|c|}{ Repeatability } & \multicolumn{3}{|c|}{ Intermediate } \\
\hline & Peak area & SD & $\%$ RSD & Peak area & SD & $\%$ RSD \\
\hline Clindamycine & 1395906 & 9591 & 0.69 & 1380208 & 6542.5 & 0.5 \\
\hline Metronidazole & 1683511 & 20795.4 & 1.24 & 1664365 & 7445.1 & 0.4 \\
\hline Clotrimazole & 1313833 & 11668.4 & 0.89 & 1301211 & 4174 & 0.3 \\
\hline
\end{tabular}

SD: Standard deviation, RSD: Relative standard deviation 


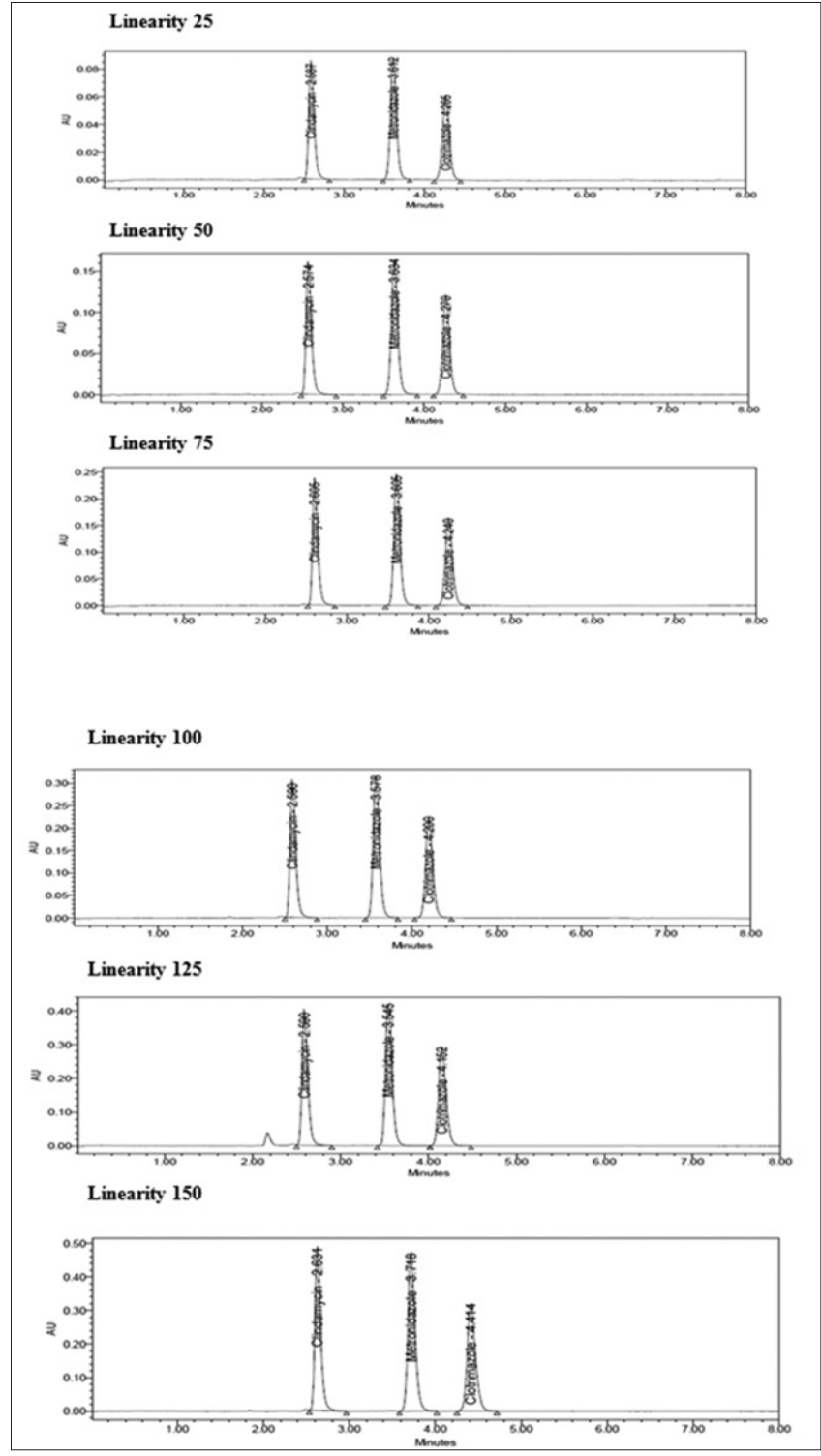

Fig. 2: Linearity chromatograms

and Clotrimazole were stable under forced thermal degradation, photolytic, and neutral degradations. From the degradation studies, Peak purity test results derived from PDA detector confirmed that the Clindamycine, Metronidazole, and Clotrimazole peaks were homogeneous and pure in all the analyzed stress samples (Table 9). The mass balance of stressed samples was close to $94.50 \%$. Purity plots were shown in Fig. 3. Forced Degradation results are tabulated in Table 9.

\section{CONCLUSION}

Finally, we are successful in developing and validating a new, simple, rapid, and precise stability indicating HPLC method was for the simultaneous estimation of Clindamycine, Metronidazole, and Clotrimazole in pharmaceutical dosage form, with less complex mobile phase and runtime compared to available (published) methods.

Applied the validated method for estimating assay of Clindamycine, Metronidazole, and Clotrimazole in the formulation of Vagi CL. Formulation of Vagi CL having a lot of advantages for treating of amoebiasis, anaerobic infections, and antibiotic-associated colitis. Till date, no official methods developed for a combination of Vagi CL. Hence, this method can be applied
Table 4: Determination of accuracy of Clindamycine

\begin{tabular}{llll}
\hline \% Level & $\begin{array}{l}\text { Amount } \\
\text { spiked } \\
(\boldsymbol{\mu g} / \mathbf{m l})\end{array}$ & $\begin{array}{l}\text { Amount } \\
\text { recovered } \\
(\boldsymbol{\mu g} / \mathbf{m l})\end{array}$ & \% Recovery \\
\hline 50 & 50 & 49.86 & 99.72 \\
& & 50.67 & 101.34 \\
100 & \multirow{2}{*}{100} & 49.95 & 99.89 \\
& & 102.09 & 102.09 \\
150 & & 101.75 & 101.75 \\
& 150 & 100.80 & 100.80 \\
& & 152.65 & 101.76 \\
Mean \%recovery & & 151.47 & 100.52 \\
Standard & & & 100.98 \\
deviation & & & 0.8354 \\
Relative & & \\
standard \\
deviation in \%
\end{tabular}

Table 5: Determination of accuracy of Metronidazole

\begin{tabular}{llll}
\hline \% Level & $\begin{array}{l}\text { Amount } \\
\text { spiked } \\
(\boldsymbol{\mu g} / \mathbf{m l})\end{array}$ & $\begin{array}{l}\text { Amount } \\
\text { recovered } \\
(\boldsymbol{\mu g} / \mathbf{m l})\end{array}$ & \% Recovery \\
\hline 50 & 50 & 50.76 & 101.52 \\
& & 50.09 & 100.18 \\
100 & \multirow{2}{*}{100} & 50.38 & 100.76 \\
& & 101.34 & 101.34 \\
150 & 150 & 100.93 & 100.93 \\
& & 100.19 & 100.19 \\
Mean \%recovery & & 151.39 & 99.31 \\
Standard deviation & & 152.05 & 100.92 \\
Relative standard & & & 100.36 \\
deviation in \% & & & 0.7137 \\
\hline
\end{tabular}

Table 6: Determination of accuracy of Clotrimazole

\begin{tabular}{llll}
\hline \% Level & $\begin{array}{l}\text { Amount } \\
\text { spiked } \\
(\boldsymbol{\mu g} / \mathbf{m l})\end{array}$ & $\begin{array}{l}\text { Amount } \\
\text { recovered } \\
(\boldsymbol{\mu g} / \mathbf{m l})\end{array}$ & \% Recovery \\
\hline 50 & 50 & 50.02 & 100.03 \\
& & 50.95 & 101.91 \\
100 & \multirow{2}{*}{100} & 50.46 & 100.92 \\
& & 101.19 & 101.19 \\
150 & 150 & 100.59 & 100.59 \\
& & 100.76 & 100.76 \\
Mean \%recovery & & 151.36 & 99.39 \\
Standard deviation & & 150.77 & 100.91 \\
Relative standard & & & 100.61 \\
deviation in \% & & & 0.7073 \\
\hline
\end{tabular}

Table 7: Sensitivity table of Clindamycine, Metronidazole, and Clotrimazole

\begin{tabular}{lll}
\hline Molecule & LOD $(\mu \mathrm{g} / \mathbf{m l})$ & LOQ $(\mu \mathrm{g} / \mathbf{m l})$ \\
\hline Clindamycine & 0.194 & 0.589 \\
Metronidazole & 0.095 & 0.290 \\
Clotrimazole & 0.135 & 0.412 \\
\hline
\end{tabular}

LOD: Limit of detection, LOQ: Limit of quantification 
Table 8: Robustness data for Clindamycine, Metronidazole, and Clotrimazole

\begin{tabular}{|c|c|c|c|c|}
\hline S. No & Condition & $\%$ RSD of Clindamycine & \%RSD of Metronidazole & $\%$ RSD of Clotrimazole \\
\hline 1 & Flow rate $(-) 0.9 \mathrm{ml} /$ minutes & 0.6 & 0.6 & 0.4 \\
\hline 2 & Flow rate $(+) 1.1 \mathrm{ml} /$ minutes & 0.2 & 0.2 & 0.3 \\
\hline 3 & Mobile phase (-) 50b: 50a & 1.1 & 0.4 & 0.2 \\
\hline 4 & Mobile phase (+) 40b: $60 \mathrm{a}$ & 0.4 & 0.4 & 0.4 \\
\hline 5 & Temperature $(-) 25^{\circ} \mathrm{C}$ & 0.8 & 0.8 & 0.8 \\
\hline 6 & Temperature $(+) 35^{\circ} \mathrm{C}$ & 0.3 & 0.4 & 0.2 \\
\hline
\end{tabular}

RSD: Relative standard deviation

Table 9: Forced degradation results of proposed RP-HPLC method

\begin{tabular}{|c|c|c|c|c|c|c|c|c|c|}
\hline \multirow{2}{*}{$\begin{array}{l}\text { Degradation } \\
\text { condition }\end{array}$} & \multicolumn{3}{|c|}{ Clindamycine } & \multicolumn{3}{|c|}{ Metronidazole } & \multicolumn{3}{|c|}{ Clotrimazole } \\
\hline & $\begin{array}{l}\text { \% Drug } \\
\text { degraded }\end{array}$ & $\begin{array}{l}\text { Purity } \\
\text { angle }\end{array}$ & $\begin{array}{l}\text { Purity } \\
\text { threshold }\end{array}$ & $\begin{array}{l}\text { \% Drug } \\
\text { degraded }\end{array}$ & $\begin{array}{l}\text { Purity } \\
\text { angle }\end{array}$ & $\begin{array}{l}\text { Purity } \\
\text { threshold }\end{array}$ & $\begin{array}{l}\text { \% Drug } \\
\text { degraded }\end{array}$ & $\begin{array}{l}\text { Purity } \\
\text { angle }\end{array}$ & $\begin{array}{l}\text { Purity } \\
\text { threshold }\end{array}$ \\
\hline Acid & 3.97 & 0.13 & 0.37 & 3.64 & 0.11 & 0.31 & 3.03 & 0.18 & 0.35 \\
\hline Alkali & 2.52 & 0.18 & 0.42 & 2.94 & 0.10 & 0.33 & 2.12 & 0.13 & 0.36 \\
\hline Oxidation & 5.50 & 0.15 & 0.39 & 5.21 & 0.19 & 0.35 & 4.41 & 0.21 & 0.44 \\
\hline Thermal & 0.70 & 0.10 & 0.47 & 0.89 & 0.22 & 0.53 & 0.75 & 0.34 & 0.79 \\
\hline Water & 0.40 & 0.19 & 0.39 & 0.94 & 0.10 & 0.35 & 0.72 & 0.16 & 0.42 \\
\hline
\end{tabular}

RP-HPLC: Reverse phase-high performance liquid chromatography, UV: Ultraviolet

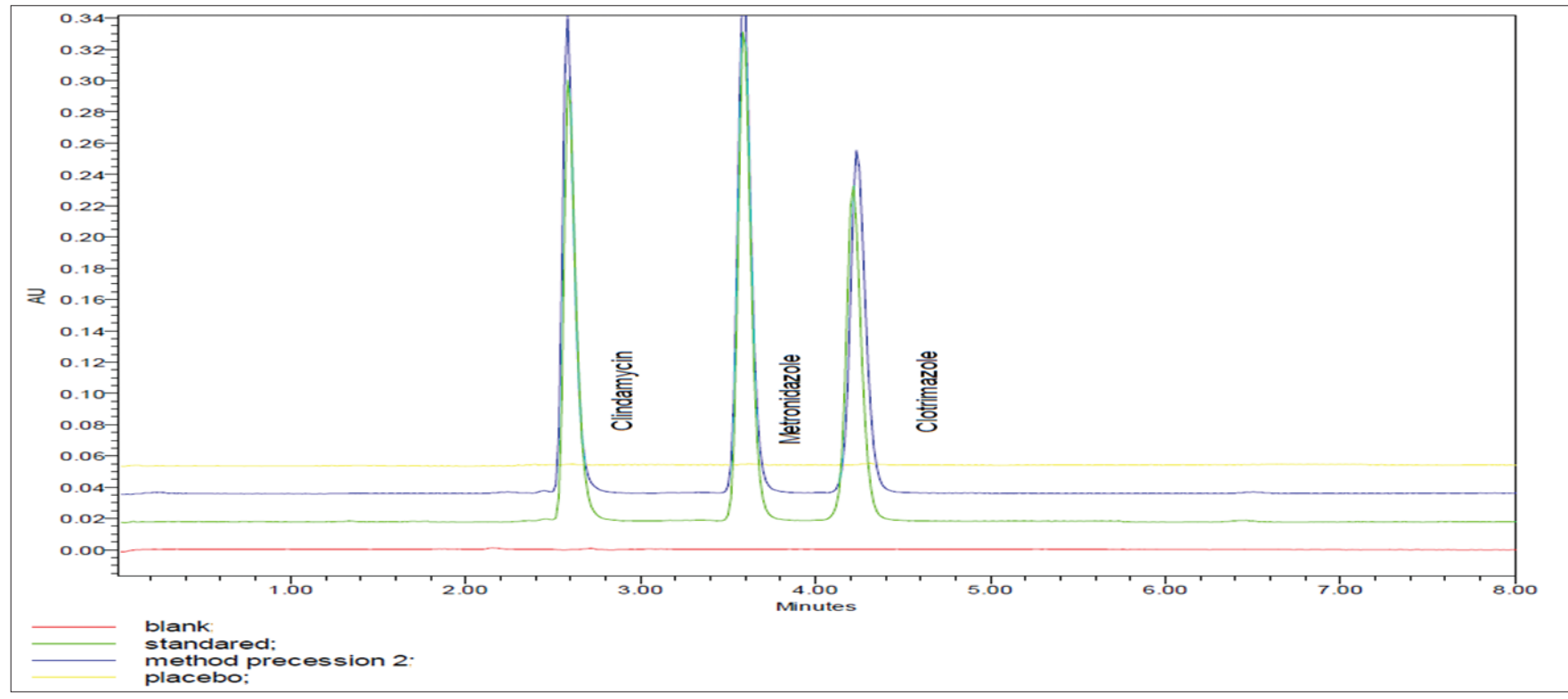

Fig. 3: Specificity overlay chromatogram of blank, standard, placebo, and marketed sample of Clindamycine, Metronidazole, and Clotrimazole

for the estimation of Clindamycine, Metronidazole, and Clotrimazole in drug testing laboratories and pharmaceutical industries.

\section{ACKNOWLEDGMENTS}

The authors were thankful for the Spectrum Pharma Research Solutions, Hyderabad, for providing Clindamycine, Metronidazole, and Clotrimazole reference standards as a gift sample to carry out the research work.

\section{REFERENCES}

1. Daum RS. Clinical practice. Skin and soft-tissue infections caused by methicillin-resistant Staphylococcus aureus. N Engl J Med 2007;357(4):380-90.

2. Klempner MS, Styrt B. Clindamycin uptake by human neutrophils. J Infect Dis 1981;144(5):472-9.

3. Li LH, Kuentzel SL, Shugars KD, Bhuyan BK. Cytotoxicity of several marketed antibiotics on mammalian cells in culture. J Antibiot (Tokyo) 1977;30(6):506-12.
4. Shennan A, Crawshaw S, Briley A, Hawken J, Seed P, Jones G, et al. A randomised controlled trial of metronidazole for the prevention of preterm birth in women positive for cervicovaginal fetal fibronectin: The PREMET study. BJOG 2006;113(1):65-74.

5. Lamont RF. Can antibiotics prevent preterm birth-the pro and con debate. BJOG 2005;112 Suppl 1:67-73.

6. Williams CS, Woodcock KR. Do ethanol and metronidazole interact to produce a disulfiram-like reaction? Ann Pharmacother 2000;34(2):255-7.

7. Visapää JP, Tillonen JS, Kaihovaara PS, Salaspuro MP. Lack of disulfiram-like reaction with metronidazole and ethanol. Ann Pharmacother 2002;36(6):971-4.

8. Sawyer PR, Brogden RN, Pinder RM, Speight TM, Avery. Clotrimazole A review of its antifungal activity and therapeutic efficacy. Drugs 1975;9(6):424-47.

9. Jensen BS, Strøbaek D, Olesen SP, Christophersen P. The $\mathrm{Ca}^{+}$activated $\mathrm{K}^{+}$channel of intermediate conductance: A molecular target for novel treatments? Curr Drug Targets 2001;2(6):401-22.

10. Carrillo-Muñoz AJ, Brió S, Alonso R, del Valle O, Santos P, Quindós G. 
Ciclopiroxolamine: In vitro antifungal activity against clinical yeast isolates. Int J Antimicrob Agents 2002;20(5):375-9.

11. Seethalakshmi N, Chenthilnathan A, Rama K. RP-HPLC method development and validation for simultaneous estimation of metronidazole, clindamycine phosphate and clotrimazole in combined pharmaceutical dosage forms. Int Res J Pharm Appl Sci 2014;4(2):67-77.

12. Rajendar L. A stability indicating RP-HPLC method for the simultaneous estimation of metronidazole, clindamycine and clotrimazole in bulk and their combined dosage form. World J Pharm Sci 2014;3(1):93-103.

13. ICH. Stability Testing of New Drug Substances and Products. Geneva: International Conference on Harmonization, IFPMA; 1993.

14. ICH. Harmonised Tripartite Guideline, Stability Testing Of New Drug Substances and Products Q1A(R2); 2003.

15. ICH, Q2B. Harmonized tripartite guideline, Validation of analytical procedure Methodology. Geneva, Switzerland: International Conference on Harmonization; 1996.

16. ICH. Guidance on Analytical Method Validation, International Convention on Quality for the Pharmaceutical Industry. Toronto, Canada: International Conference on Harmonization; 2002.

17. ICH. Harmonised Triparitite Guidelines, Validation of Analytical
Procedures: Text and Methodology Q2(R1); 2005.

18. ICH. Stability Testing: Photo stability Testing New Drug Substances and Products. Geneva: International Conference on Harmonization, IFPMA; 1996.

19. Mastanamma SK, Rambabu G, Saidulu P, Tejaswini IS. Designing of forced degradation studies and development of validated stability indicating method for simultaneous estimation of desloratadine and montelukast odium in their formulation. Pharm Lett 2015;7:39-47.

20. Masthannamma SK, Kumar TA, Srivani GB, Sridhar TA, Naik BS, Kumar VV. Stability-indicating validated reversed phasehigh performance liquid chromatography method for simultaneous determination of cobicistat and atazanavir sulfate in bulk and pharmaceutical dosage form. Asian J Pharm Clin Res 2016;9(3):62-70.

21. Saidulu P, Mastanamma SK. Stability indicating gradient RP-HPLC method for the simultaneous estimation of lamivudine, abacavir and dolutegravir in bulk and their combined dosage form. Int J Pharm Sci Rev Res 2016;37:249-57.

22. Revathi Naga Lakshmi P, Prahlad P, Mastanamma SK, Ravindra N, Rao MV.UPLC separation analysis of emtricitabine, tenofovir, cobicistat and elvitegravir from their degradation products. Int J Pharm Pharm Sci 2016;8(4);362-9. 